Jap. J. vet. Sci., 40, 275 281 (1978)

\title{
Isolation of Fusobacterium necrophorum from Bovine Ruminal Lesions
}

\author{
Masamitsu KANOE, Yūji IZUCHI and Mitsuyoshi TODA \\ Division of Veterinary Science, Faculty of Agriculture, \\ Yamaguchi University, Yamaguchi-shi, Yamaguchi 753
}

(Received for publication October 18, 1977)

\begin{abstract}
A survey was conducted on the occurrences of rumen parakeratosis, rumenitis, traumatic reticulitis, and reticular and hepatic abscesses among 492 slaughtered cattle in Yamaguchi and Fukuoka Prefectures, Japan. These diseases occurred to 59 animals (12.0\%), $83(16.9 \%), 26(5.3 \%)$ and $25(5.1 \%)$, respectively. Hepatic abscesses were detected from 18 $(12.0 \%)$ of 149 animals with rumen parakeratosis and/or rumenitis, $3(11.5 \%)$ of 26 with traumatic reticulitis, $1(12.5 \%)$ of 8 with reticular abscesses, and $3(1.0 \%)$ of 309 with no disorders. Fusobacterium necrophorum was detected from 9 of 20 cases of rumen parakeratosis, 12 of 20 cases of rumenitis, 1 of 10 cases of unaffected ruminal tissue, and all of the cases of reticular and hepatic abscesses. The viable count of $F$. necrophorum was $10^{4}$ to $10^{6}$ per gram in the cases of rumen parakeratosis, $10^{3}$ to $10^{7}$ in those of rumenitis, and $10^{5}$ in that of unaffected ruminal tissue.
\end{abstract}

Relatively frequent occurrence of hepatic abscess has hitherto been described in barley beef and feedlot beef cattle by several workers $[4,6,10]$. In Japan, a similar finding has recently been obtained from fattened dairy steers $[1,12,15]$. In these animals, attention was paid to a correlation between the incidence of hepatic abscess and that of ruminal lesions, such as rumen parakeratosis and rumenitis. Consequently, the terms rumenitis-liver abscess complex [4] and rumen parakeratosis-rumenitis-liver abscess complex [15] were proposed. Those previous reports, however, gave few detailed bacteriological observations, especially on Fusobacterium necrophorum.

In their previous papers, the authors reported the bacteriology of bovine hepatic abscess and the distribution of $F$. necrophorum in the alimentary tract of cattle $[7$,
8]. The present paper deals with a survey on the incidence of bovine ruminal lesions and the isolation of $F$. necrophorum, which is considered as one of the most important agents of hepatic abscess formation.

\section{Materials and Methods}

Reticulo-ruminal lesions

A total of 492 cattle slaughtered at the Ube Abattoir in Ube-shi, Yamaguchi Prefecture, and the Yahata Meat Center in Kitakyushu-shi, Fukuoka Prefecture, Japan, over a period from September, 1973 to July, 1974 were examined. By referring to the literature $[5,15]$, the reticulo-ruminal lesions grossly observed in them were recorded as follows.

Rumen parakeratosis: Lesions were grossly characterized by spotted adhesion of feed and hairs to the mucosal epithelium of the rumen, and clumping, enlargement and black pigmentation of villi.

Rumenitis: Foci of lesions grossly exhibited necrosis, swelling, edema and hemorrhage in the mucosa. Some areas of the mucosa manifested devillation, often depigmentation, ulcers, nodules of

ウシの第一胃病集からの Fusobacterium necrophorum の分離：鹿江雅光・井土裕児・戸田光敬（山口大学農 学部獣医学科) 
granulation tissue, and scars.

Traumatic reticulitis and reticular abscess: At slaughter, foreign bodies, such as ingested metal fragments and similar rigid materials, were grossly found in the lumen of the reticulum and in reticular abscesses. For convenience sake, lesions without these bodies were regarded as reticular abscesses. Isolation and enumeration of $F$. necrophorum

Twenty samples of rumen parakeratosis, 20 of rumenitis, 25 of hepatic abscesses, and 8 reticular abscesses were collected in a chilled container for laboratory examination. A total of $10 \mathrm{~L}$ samples of rumen fluids were obtained from animals with these lesions and 10 samples from those with apparently unaffected ruminal mucous membrane. All the samples were brought to the laboratory in the same manner.

Homogenized tissues with and without lesions, rumen fluids, and pura were used for the isolation and enumeration of $F$. necrophorum. Instead of FM medium (Nissui Seiyaku Co., Ltd., Tokyo), 5\% rabbit blood FM medium (BFM) was routinely employed. The cultivation, identification, enumeration and differentiation of the isolates were made by referring to previous reports $[2,3,7,8,10]$.

\section{Results}

Incidence of bovine reticulo-ruminal lesions

Of the 492 cattle examined, $149(30.3 \%)$ were affected with varying degrees of rumen parakeratosis and/or rumenitis (Figs. 1 and 2). As shown in Table 1, the former disease was detected from $59(12.0 \%)$ animals and the latter from $83(16.9 \%)$. Both diseases were observed in $7(1.4 \%)$ animals. Reticular abscess was found in $8(1.6 \%)$ ani- mals and traumatic reticulitis in $26(5.3 \%)$. The breeds and sexes of these animals are listed in Table 2. In Holstein steers, reticulo-ruminal lesions were detected from $74(54.0 \%)$ of 137 animals of varying age. Table 3 indicates the occurrence of hepatic abscess. This abscess was found in 18 $(12.0 \%)$ of 149 animals with ruminal lesions, $3(11.5 \%)$ of 26 with traumatic reticulitis, $1(12.5 \%)$ of 8 with reticular abscess, and $3(1.0 \%)$ of 309 with no diseases. Isolation and colony count of $F$. necrophorum

Mucous membrane: As shown in Table 4, F. necrophorum was found in 9 of 20 specimens of rumen parakeratosis, 12 of 20 specimens of rumenitis, and 1 of 10 unaffected tissue specimens. The colony count of the organism was $10^{4}$ to $10^{6}, 10^{3}$ to $10^{7}$ and $10^{5}$ per gram, respectively.

Rumen fluid: $F$. necrophorum was detected from 59 of 101 specimens affected with rumen parakeratosis and/or rumenitis. The bacterial count ranged from $10^{2}$ to $10^{6}$.

Abscess: The organism was detected from all the specimens of hepatic and reticular abscesses. The viable bacterial count of $F$. necrophorum ranged from $10^{4}$ to $10^{8}$ per gram in 22 specimens of hepatic abscess. It was not examined in the remaining specimens.

Table 1. Occurrence of bovine reticulo-ruminal lesions

\begin{tabular}{lccr}
\hline Lesion & Ubattoir & Yahata & Total $(\%)$ \\
\hline Rumen parakeratosis & $21^{*}$ & 38 & $59(12.0 \%)$ \\
Rumenitis & 57 & 26 & $83(16.9 \%)$ \\
Rumen parakeratosis & 2 & 5 & $7(1.4 \%)$ \\
and rumenitis & 11 & 15 & $26(5.3 \%)$ \\
Traumatic reticulitis & 6 & 2 & $8(1.6 \%)$ \\
Reticular abscess & 157 & 152 & $309(62.8 \%)$ \\
Unaffected mucous mernbrane & 254 & 238 & $492(100 \%)$ \\
\hline Total & & & \\
\hline Remarks. & & &
\end{tabular}


Table 2. Breed and sex of cattle with reticulo-ruminal lesions

\begin{tabular}{|c|c|c|c|}
\hline Breed & Sex & $\begin{array}{l}\text { No. of animals } \\
\text { inspected }\end{array}$ & $\begin{array}{l}\text { No. of animals } \\
\text { with lesions }\end{array}$ \\
\hline \multirow{3}{*}{ Holstein } & TMale & 25 & 6 \\
\hline & Female & 88 & 26 \\
\hline & LSteer & 137 & 74 \\
\hline \multirow{3}{*}{$\begin{array}{l}\text { Japanese } \\
\text { Black }\end{array}$} & Male & 2 & 0 \\
\hline & Female & 23 & 9 \\
\hline & LSteer & 106 & 29 \\
\hline \multirow{4}{*}{$\begin{array}{l}\text { Japanese } \\
\text { Brown }\end{array}$} & TMale & 7 & 1 \\
\hline & Female & 16 & 7 \\
\hline & LSteer & 88 & 31 \\
\hline & Total & 492 & $183(37.2 \%)$ \\
\hline
\end{tabular}

Table 3. Relationship between hepatic abscess and reticulo-ruminal lesions

\begin{tabular}{lcrr}
\hline & \multicolumn{2}{c}{ Hepatic abscess } & \multirow{2}{*}{ Total } \\
\cline { 2 - 3 } & + & - & \\
\hline Rumen parakeratosis & $13^{*}$ & 46 & 59 \\
Rumenitis & 3 & 80 & 83 \\
Rumen parakeratosis and rumenitis & 2 & 5 & 7 \\
Traumatic reticulitis & 3 & 23 & 26 \\
Reticular abscess & 1 & 7 & 8 \\
Unaffected mucous membrane & 3 & 306 & 309 \\
\hline \multicolumn{1}{c}{ Total } & 25 & 467 & 492 \\
\hline Remarks. & & & \\
* No. of animals. &
\end{tabular}

Table 4. Isolation and colony count of F. necrophorum

\begin{tabular}{|c|c|c|c|c|c|c|c|c|c|}
\hline & \multirow{2}{*}{ Sample } & \multirow{2}{*}{$\begin{array}{l}\text { Isolation } \\
\text { rafe }\end{array}$} & \multicolumn{7}{|c|}{ Colony count $\left(\log _{10}\right)$} \\
\hline & & & 2 & 3 & 4 & 5 & 6 & 7 & 8 \\
\hline \multirow{3}{*}{$\begin{array}{l}\text { Mucous } \\
\text { membrane }\end{array}$} & Rumen parakeratosis & $9 / 20 *$ & 0 & 0 & 5 & 3 & 1 & 0 & 0 \\
\hline & Rumenitis & $12 / 20$ & 0 & 2 & 2 & 2 & 5 & 1 & 0 \\
\hline & Unaffected & $1 / 10$ & 0 & 0 & 0 & 1 & 0 & 0 & 0 \\
\hline \multirow{5}{*}{$\begin{array}{l}\text { Rumen } \\
\text { fluid }\end{array}$} & Rumen parakeratosis & $20 / 32$ & 0 & 3 & 10 & 6 & 1 & 0 & 0 \\
\hline & Rumenitis & $37 / 64$ & 1 & 9 & 14 & 11 & 2 & 0 & 0 \\
\hline & $\begin{array}{l}\text { Rumen parakeratosis } \\
\text { and rumenitis }\end{array}$ & $2 / 5$ & 0 & 0 & 0 & 1 & 1 & 0 & 0 \\
\hline & Hepatic abscess & $22 / 22$ & 0 & 0 & 2 & 3 & 7 & 8 & 2 \\
\hline & Reticular abscess & $8 / 8$ & *** & • & $\cdot$ & - & - & • & - \\
\hline
\end{tabular}

Remarks.

*: No. of positive samples/No. of samples examined.

**: Not tested. 
Distribution of phases of $F$. necrophorum

Based on biological properties, the isolates were differentiated into two phases, A and $\mathrm{B}$. The organism belonging to phase A was detected from 19 specimens of ruminal mucous membrane and fluid, 22 specimens of hepatic abscess, and 3 specimens of reticular lesion, and that belonging to phase $\mathrm{B}$ from 64,3 and 5 specimens, respectively.

\section{Discussion}

Relatively high incidences of rumen parakeratosis and rumenitis in beef cattle and steers have been reported in U.S.A. and the northern district of Japan in the recent years. In the present survey, this finding was observed in Holstein steers. In order to clarify the predisposing factors of these diseases, several worker's investigated the feeds and fattening process of these animals in detail $[1,5,15]$. No attempts succeeded in elucidating any definite cause for this finding.

Hepatic abscess occurred quite frequently to cattle with ruminal lesions and traumatic reticulitis. Jensen [4] reported a significant correlation between bovine rumenitis and hepatic abscess, and proposed the term "rumenitis-liver abscess complex". Later, Tamate [15] used the term "rurnen parakeratosis-rumenitis-liver abscess complex". On the other hand, it is generally considered that both traumatic reticulitis and reticular abscess are predisposing conditions for hepatic abscess formation. It seems necessary to pay attention to the incidence of these lesions together with those of rumen parakeratosis and rumenitis. It is a future subject of study to elucidate the correlation between hepatic abscess and these reticulo-ruminal lesions.

$F$. necrophorum was detected from lesions of the ruminal walls and from reticular abscesses. No specimens of traumatic reticulitis were collected. In some specimens of rumenitis, the viable count of the organism was relatively high. On the other hand, the bacterium was not frequently detected from the apparently unaffected ruminal mucous membrane. These findings may indicate the participation of $F$. necrophorum in causing an injury of the ruminal mucous membrane, and the presence of a significant correlation between reticuloruminal lesions and hepatic abscess. Jensen [5] described the inability of the organism to penetrate into the unaffected, intact mucous membrane. Recently, the bacterium was detected from the sound hepatic tissue around the abscess [1, 13]. It seems necessary to investigate the problem how $F$. necrophorum in the ruminal content penetrates into veins in the ruminal wall and reaches the hepatic tissue. It is also needed to clarify the virulence factors of the bacterium.

Reports [2, 3, 7] have hitherto been made on several biotypes of strains of $F$. necrophorum divided by the difference in biological properties. The present isolates were tentatively differentiated into two phases by referring to Bergey's Manual [2]. On the other hand, it is well known that the organism is distributed in wide ranges of domestic and wild animals [9, 14]. Details in the biological, serological and pathogenic properties of the bacterium from these sources remain to be elucidated. Attempts should be made in near future to compare several properties between the two phases by obtaining isolates from more different sources. The results of comparison will contribute to a more efficient differentiation of the bacterium and to the establishment of an adequate infrasubspecific designation, the term which has appeared in the recommendation by Lapage et al. 
$[10]$.

Acknowledgments: The authors wish to thank Professor A. Sato, of the Department of Veterinary Pathology, Faculty of Agriculture, Yamaguchi University, for his valuable advice, and the staff officers of the Ube Health Center, Yamaguchi Prefecture, and of the Yahata Meat Center, City of Kitakyushu, Fukuoka Prefecture, for the cooperation in collecting samples.

\section{References}

[1] Azuma, R. (1976). Animal diseases caused by anaerobic bacteria. J. Jap. vet. med. Ass., 29, 361-370 (in Japanese).

[2] Buchanan, R. E., and Gibbons, N. E. (1974). In Bergey's Manual of Determinative Bacteriology, 8th ed., Williams and Wilkins, Baltimore, 409-411.

[3] Fievez, L. (1963). In Etude comparée des Souches de Sphaerophorus necrophorus isolées chez l'Homme et l'Animal, Presses Académiques Européennes, Bruxelles, 86.

[4] Jensen, R., Deane, H. M., Cooper, L. J., Miller, V. A., and Graham, W. R. (1954). The rumenitic-liver abscess complex in beef cattle. Amer. J. vet. Res., 15, 202-216.

[5] Jensen, R., and Mackey, D. R. (1971). In Diseases of Feedlot Gattle, 2nd ed., Lea and Febiger, Philadelphia, 101-109 and 279-284.

[6] Jönson, G., and Lieberg, P. (1974). Liver abscesses in intensively fed cattle. Acta vet. scand., 15, 264-273.

[7] Kanoe, M., Imagawa, H., and Toda, M. (1975). Distribution of Fusobacterium necrophorum in bovine alimentary tracts. Bull. Fac. Agr. Yamaguti Univ., No. 26, 161-172.

[8] Kanoe, M., Imagawa, H., Toda, M., Sato, A., Inoue, M., and Yoshimoto, Y. (1976). Bacteriology of bovine hepatic abscesses. Jap. J. vet. Sci., 38, 263-268.

[9] Koosaka, S. (1974). Studies on Gram-negative anaerobic rods in the fecal flora of animals. II. Distribution of Gram-negative anaerobic rods in feces of rabbits and mice. Jap. J. vet. Sci., 36, 231-236 (in Japanese).

[10] Lapage, S. P., Sneath, P. H. A., Lessel, E. F., Skerman, V. B. D., Seeliger, H. P. R., and Clark, W. A. (1975). In International Code of Nomenclature of Bacteria, 1976 revision, Int. Microbiol. Soc. by Amer. Soc. Microbiol,, Washington, D.C., 125-127.

[11] Rowland, A. C. (1966). Some aspects of the rumenitis/liver abscess complex in traditional and in intensively managed beef cattle. Vet. Rec., 78, 713-716.

[12] Shimada, Y. (1971). Hepatic abscesses found in fattening steers and its control. Juikai, No. 97, 24-34 (in Japanese).

[13] Shinjo, T., Masuda, N., Shiraishi, F., Nakura, M., Nakamura, N., and Tamada, S. (1975). Studies on bovine hepatic abscesses. II. Bacteriological examination of abscesses and normal tissues. The 80th Meeting of Jap. Soc. Vet. Sci.

[14] Simon, P. C., and Stovell, P. L. (1969). Diseases of animals associated with Sphaerophorus necrophorus: Characteristics of the organism. Vet. Bull., 39, 311-315.

[15] Tamate, H. (1973). High incidence of ruminal lesions and liver abscess in beef associated with intensive fattening in Miyagi Prefecture. Tohoku J. agr. Res., 23, 184-195.

\section{Explanation of Figures}

Fig. 1. Rumen parakeratosis of ventral sac of rumen. Clumps of villi with feed and hair are evident.
Fig. 2. Rumenitis of ventral sac of rumen. Mucosa is hemorrhagic, devillated and erosive. 

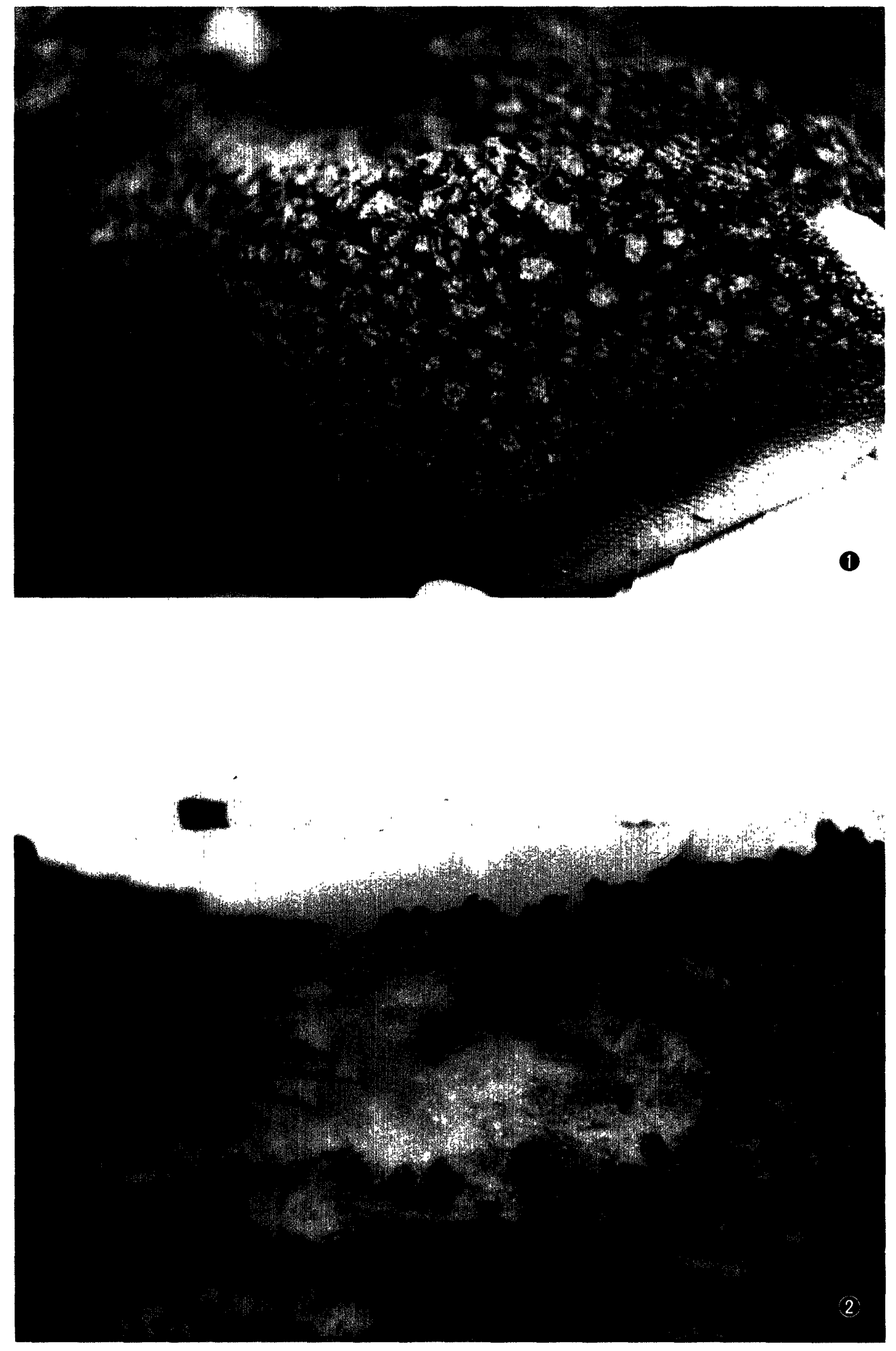